\title{
RESTRUCTURING CHALLENGES IN THE OIL AND GAS SECTOR: THE TREATMENT OF REgUlatory ORDERS POST-REDWATER
}

\author{
KELLY BOURASSA, RYAN ZAHARA, ${ }^{* *}$ \\ AND CHRIS NYBERG ${ }^{* * *}$
}

\begin{abstract}
Companies within the Alberta energy sector are currently unable to satisfy amounts outstanding to their creditors and at the same time fulfill their environmental responsibilities, culminating in a fight over whether provincial or federal statutes have priority when it comes to the environmental obligations of insolvent oil and gas companies. This article identifies recent legal developments relevant to corporate restructurings in the Alberta energy sector, examining the Alberta Energy Regulator's treatment of exploration and production companies, the licensee liability rating program, and the practical challenges that Alberta Energy Regulator's licensees and creditors face in the current economic and regulatory climate. Finally, this article analyzes options for facilitating the sale of licenced assets.
\end{abstract}

\section{TABLE OF CONTENTS}

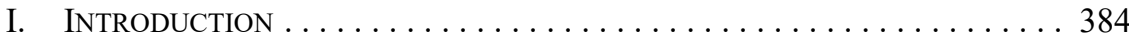

II. THE AER'S APPROACH TO INSOLVENCY $\ldots \ldots \ldots \ldots \ldots \ldots \ldots \ldots$

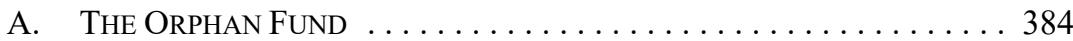

B. The ORPhan Fund Well ASSOCIATION $\ldots \ldots \ldots \ldots \ldots \ldots \ldots$

C. The Alberta Licensing Regime . . . . . . . . . . . . . . . 386

D. ABANDONMENT AND THE ORPHAN PROCESS ............ 390

E. The STATUS OF ABANDONMENT OBLIGATIONS IN ALBERTA . . . . . . . . . . . . . . . . 392

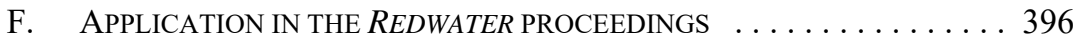

G. Disclaiming the Renounced Assets . . . . . . . . . . . . . . 397

H. THE ABANDONMENT ORDERS are Provable Claims . . . . . . . . . . . . . . . . . . . . 400

III. MOVING ForWARD POST-REDWATER: Facilitating the SALE of E\&P COMPanies' AsSETS . . . . . . . . 407

A. IMPLICATIONS OF REDWATER $\ldots \ldots \ldots \ldots \ldots \ldots \ldots \ldots \ldots \ldots \ldots$

B. SumMARY OF OPTIONS $\ldots \ldots \ldots \ldots \ldots \ldots \ldots \ldots \ldots \ldots$

C. Regulator-Directed Transfers $\ldots \ldots \ldots \ldots \ldots \ldots \ldots \ldots 408$

D. Negotiating With the AER . . . . . . . . . . . . . . . . . 409

E. BUSINESS CORPORATION ACT OPTIONS ................ 411

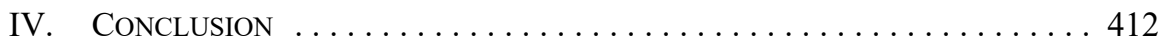

APPENDIX A ............................... 413

** $\quad$ Partner, Blake, Cassels \& Graydon LLP, Calgary, Alberta.

**** $\quad$ Partner, Blake, Cassels \& Graydon LLP, Calgary, Alberta.

*** Associate, Blake, Cassels \& Graydon LLP, Calgary, Alberta. The authors of this article represented the senior secured lender (the Lender) in Redwater Energy Corporation (Re), 2016 ABQB 278. All opinions contained in this article are their own and do not reflect those of their client or their law firm. 


\section{INTRODUCTION}

The current state of the energy sector in Alberta has created an environment where companies are unable to satisfy amounts outstanding to their creditors and at the same time fulfill their environmental responsibilities. This has created a "perfect storm" that places the scheme of distribution under section 14.06 of the Bankruptcy and Insolvency Act ${ }^{1}$ and section 11.8 of the Companies' Creditors Arrangement Act ${ }^{2}$ in direct conflict with the discretion afforded to provincial regulators to ensure companies satisfy their responsibilities under provincial environmental legislation. It has culminated in a fight over whether provincial or federal statutes have priority when it comes to the environmental obligations of insolvent oil and gas companies in the post-AbitibiBowater ${ }^{3}$ world of priorities.

This article identifies recent legal developments relevant to corporate restructurings in the Alberta energy sector, referencing specific issues regarding the Oil and Gas Conservation Act ${ }^{4}$ the Pipeline Act, ${ }^{5}$ the Alberta Energy Regulator's (AER) licensee liability rating (LLR) program, and current challenges facing the AER, licensees, and lenders in the depressed energy market.

The first section examines the AER's treatment of exploration and production (E\&P) companies. It considers in-depth the issues arising out of the operation of the LLR program with respect to insolvent licensees and whether the results may offend the priority structure found in section 14.06 of the BIA when applied to prevent the sale of a debtor's assets. Further, it looks at whether a court may direct the AER to transfer the well licences of an insolvent licensee with a non-compliant LLR in the context of a court-supervised sales process.

The second section takes into account the practical challenges that AER licensees and creditors face in the current economic and regulatory climate and analyzes options for facilitating the sale of licenced assets. It reviews the factors that creditors should consider in their decision of whether to appoint an insolvency professional over a debtor's assets, and how to address the sale of environmentally challenged assets, especially those which have significant abandonment obligations associated with them.

\section{THE AER'S APPROACH TO INSOLVENCY}

\section{A. The ORPhan Fund}

Over the past five years, the AER has vigorously asserted its rights in the insolvency proceedings of E\&P companies. Its actions have included strictly enforcing against insolvent companies' (and those appointed to sell their assets) obligations as "licensees" pursuant to

RSC 1985, c B-3 [BIA]. The text of section 14.06 is attached to this article as Appendix A.

RSC 1985, c C-36 [CCAA]. While not expressly considered in Redwater Energy Corporation (Re), 2016 ABQB 278, (sub nom Grant Thornton Ltd v Alberta Energy Regulator) 33 Alta LR (6th) 221, Wittmann CJ [Redwater], section 11.8 of the CCAA contains similar language to section 14.06 of the BIA, ibid. Newfoundland and Labrador v AbitibiBowater Inc, 2012 SCC 67, [2012] 2 SCR 443, Deschamps J [AbitibiBowater].

RSA 2000, c O-6 [OGCA].

RSA 2000, c P-15 [PA]. 
provincial environmental legislation. ${ }^{6}$ In practice, this has resulted in many debtor companies being unable to sell assets or complete transactions that transfer regulatory licences. In the authors' opinion, the AER is effectively arguing for a fundamental change in the treatment of the priority of environmental claims in insolvency proceedings.

It has long been a priority of the provincial regulator to ensure that the burden of the abandonment and reclamation of orphan wells and facilities does not fall on the orphan well fund (the Orphan Fund). ${ }^{7}$ The Orphan Fund is an industry-funded account established to pay for the abandonment and reclamation of orphan properties. Specifically, it was established so that the public is not financially responsible for the cleanup and abandonment of an insolvent licensee's production facilities and to provide a method of funding subsurface abandonment. ${ }^{8}$ However, in the authors' view, the AER's actions in insolvency proceedings to date do not further the original purpose of the Orphan Fund or the current abandonment framework in Alberta.

In establishing the Orphan Fund and the orphan program, industry participants and the predecessor of the AER, the Energy Resources Conservation Board (the Board), had concerns about an increase in the number of orphan wells resulting from oil and gas operations. Industry and the Board engaged in substantial consultations at this time and the considerations and concessions made in establishing the Orphan Fund included several fundamental principles. First and foremost, the Alberta public, especially taxpayers, were not to be at risk because of the orphan well obligations of E\&P companies. ${ }^{9}$

Initially, the Board took the view that those who benefited from a well should be responsible to look after its proper abandonment. This resulted in the Board taking a fairly expansive view of who benefited from a well, including previous owners. Industry soon advanced concerns about the length of the chain of responsibility proposed by the Board and recommended that the chain be limited to the current licensee, working interest participants, and court-appointed insolvency professionals acting on behalf of any or all of those parties. ${ }^{10}$ An industry-sponsored fund was proposed to pay for the share of abandonment costs of bankrupt owners. ${ }^{11}$ The Board decided that, in addition to the industry-sponsored fund, if the public was going to be required to pay a significant amount towards solving third party environmental liabilities, the Board would implement and enforce stricter abandonment and suspension regulations during the lifetime of the wells. ${ }^{12}$

As a result of these policy changes, the Alberta orphan program has evolved since the mid-1980s from a 50 percent government-funded program to one that is presently funded almost entirely by industry. The funding scheme has been established through the operation

Redwater, supra note 2 at para 8; PA, ibid, ss $1(1)(\mathrm{c}), 1(1)(\mathrm{n})$.

JR Nichol, "Orphan Wells: Who is Responsible - For How Long and At What Cost?" (Paper delivered at the CADE/CAODC Spring Drilling Conference, 10-12 April 1991), No 91-30 at 2 [Orphan Paper]; Redwater, supra note 2 (Transcript of the proceedings at 24 (lines 11-15) [Transcript]).

For a discussion of the purpose of the Orphan Well Fund, see Alberta, Legislative Assembly, Hansard, 23rd Leg, 2nd Sess (12 April 1994) at 1111 [April Debate]; Alberta, Legislative Assembly, Hansard, 24th Leg, 4th Sess (20 March 2000) at 509 [March Debate]; Alberta, Legislative Assembly, Hansard, 24th Leg, 4th Sess (15 May 2000) at 1565-68 [May Debate].

Orphan Paper, supra note 7 at 2-3.

Ibid at 3.

Ibid.

Ibid at 4-5. 
of various AER directives and the programs included under the Liability Management Rating (LMR) program, which consists of the LLR program, the Oilfield Waste Liability (OWL) program, and the Large Facility Liability Management (LFLM) program. ${ }^{13}$

The orphan fund levy (the Orphan Fund Levy) is the primary source of funding for the Orphan Fund and is issued by the AER pursuant to section 16.530 of the Oil and Gas Conservation Rules. ${ }^{14}$ The Orphan Fund Levy represents the amount that licensees of wells, facilities, or unclaimed sites must pay to the AER in order to fund the abandonment and reclamation program to be conducted by the Alberta Oil and Gas Orphan Abandonment and Reclamation Association (OWA) for the following fiscal year. ${ }^{15}$

\section{B. The Orphan Fund Well Association}

The Alberta orphan program now operates as the OWA, a non-profit organization operating under a delegation of legislative authority by the AER, which effectively manages disbursements from the Orphan Fund. ${ }^{16}$ The OWA's Board of Directors includes representatives from the Canadian Association of Petroleum Producers, the Explorers and Producers Association of Canada, the AER, and Alberta Environment and Parks, among others. $^{17}$

Since 1992, the Orphan Fund, effectively an industry-funded initiative, has financed the reclamation of wells owned by companies that are unable or unwilling to do so. ${ }^{18}$ In 2001 , the OWA was specifically created to be an independent body with the authority to address the problem of orphan or abandoned wells in Alberta and to establish a formal abandonment process for those wells with no means of financial support. ${ }^{19}$ It is not an insurance scheme for insolvent licensees, but a safety net for the Alberta public. ${ }^{20}$ As the provincial legislature noted in 2007, Albertans benefit from this safety net in two ways: (1) "[t]hey are protected from any future liability for orphan wells"; ${ }^{21}$ and (2) they know that the stewardship of the Alberta environment, including responsibility for orphan wells, is in the OWA's hands. ${ }^{22}$

\section{The Alberta Licensing Regime}

The current legislative regime sees the AER acting in concert with the OWA to ensure that the environmental liabilities of licensees are either satisfied or minimized. Specifically, section 10 of the OGCA authorizes the AER to make rules requiring licensees and approval holders to provide deposits or other forms of security with respect to the licensing, approval, and transfer of licences. Generally, these rules have taken the form of certain directives

Alberta Energy Regulator, "Licensee Liability Rating (LLR) Program and Licence Transfer Process," Directive 006 (Calgary: AER, 17 February 2016) [Directive 006]; Orphan Paper, ibid at 2.

Oil and Gas Conservation Rules, Alta Reg 151/1971; Redwater, supra note 2 at para 34.

Oil and Gas Conservation Rules, ibid, s 16.530.

Redwater, supra note 2 at para 33.

Ibid.

Orphan Well Association, 2014/15 Annual Report (Calgary: OWA, 2015) at 4, online: <www.orphan well.ca/OWA\%202014-15\%20Ann\%20Rpt\%20Final.pdf \$.

Orphan Well Association, 2013/14 Annual Report (Calgary: OWA, 2014) at 2-3, online: <www.orphan well.ca/OWA\%202013-14\%20Ann\%20Rpt\%20Final.pdf $>$; Redwater, supra note 2 at para 33.

Redwater, ibid at para 63.

Alberta, Legislative Assembly, Hansard, 29th Leg, 1st Sess (30 April 2007) at 712.

Ibid. 
which set out when a licensee must suspend, abandon, and reclaim licenced assets and the manner and time frame within which it must do so.

Directive 006 established the LLR program, which is the specific "liability management program governing most conventional upstream oil and gas wells, facilities, and pipelines" 23 in Alberta. It was established for the express purpose of limiting the risk of the abandonment costs of wells, associated facilities, and pipelines from being borne by the Orphan Fund. ${ }^{24}$ It is primarily focused on obtaining security deposits for the purpose of reducing the exposure of the Orphan Fund to abandonment and reclamation costs of insolvent or defunct licensees. This purpose is highlighted by the following summary of provisions contained in Directive 006 and its appendices:

(a) a security deposit, as calculated pursuant to an LMR assessment, may be "required [by the AER] to minimize the possibility of the licensee's suspension, abandonment, remediation, and reclamation costs being borne by the Orphan Fund"; 25

(b) where the AER requires a licensee to provide a security deposit, it "will be advised in writing of the amount ... required [for the deposit] and the date by which [it] must be received"; 26

(c) if a security deposit is required after the receipt of a licence transfer application, the security deposit must be provided to the AER before the licence transfer application will be approved; ${ }^{27}$ and

(d) the deemed liability of a producer licensee is the sum of the costs to suspend, abandon, remediate, and reclaim all wells and facilities for which it is the licensee, adjusted for status (active, inactive, abandoned, and problem site designation). ${ }^{28}$

A licensee's LMR is the "ratio of [its] eligible deemed assets in the LLR, LFP, and [OWL] programs to its deemed liabilities" 29 in the same. For the purposes of calculating the LLR, a licensee's deemed asset values are calculated using a formula based on the licensee's previous 12 months of reported oil and gas production (using $\mathrm{m} 3 \mathrm{OE}$ ) multiplied by the threeyear average industry netback established by the AER. ${ }^{30}$ The deemed liability values represent the AER's estimate of the cost of suspending, abandoning, remediating, and reclaiming "all wells and facilities for which it is the licensee." 31

If the LMR of a licensee is less than 1.0, the AER will require that the licensee provide it with a security deposit in order to partially or entirely secure the estimated costs of

Directive 006, supra note $13, \mathrm{~s} 4$.

Ibid, s 1 .

Ibid, s 5 .

Ibid, s 6 .

Ibid, Appendix 2 (s 8).

Ibid, s 7.2, Appendix 4

Ibid, s 4.

Ibid, Appendix 5.

Ibid, Appendix 6. See also Alberta Energy Regulator, “ Licensee Liability Rating (LLR) Program: Updated Industry Parameters and Liability Costs," Directive 011 (Calgary: AER, 31 March 2015). 
suspending, abandoning, or reclaiming a well or facility, providing care and custody for a well or facility, or carrying out any other activities necessary to ensure the protection of the public and the environment. ${ }^{32}$ The amount of the security deposit required by the AER is the difference between a licensee's deemed asset value pursuant to Directive 006, which includes previously provided security deposits, if any, and its deemed liabilities. ${ }^{33}$

The AER conducts LMR assessments for each licensee on the first Saturday of every month. ${ }^{34}$ Additionally, Directive 006 requires that an LMR assessment be conducted after receipt of a licence transfer application and prior to a transfer decision being issued. ${ }^{35}$

In order to mitigate the risk that abandonment and reclamation costs will be borne by the Orphan Fund, the AER has relied upon the licence transfer requirements found in section 24 of the OGCA and Directive 006 in order to evaluate whether licensees are able to meet their abandonment and reclamation obligations. ${ }^{36}$ Where there is a risk that a licensee will not be able to satisfy its abandonment and reclamation obligations, as represented by its LMR, the AER requires that the licensee provide a security deposit prior to the approval of its licence transfer application. ${ }^{37}$

On 1 May 2013, the Board began a three year process of implementing significant changes to its abandonment liability program and licence transfer process after extensive consultation with the Canadian Association of Petroleum Producers and other industry organizations. ${ }^{38}$ The changes were implemented to address the Board's concerns that abandonment and reclamation obligations had historically been significantly underestimated. ${ }^{39}$ Some notable changes included the following:

- $\quad$ a 25 percent increase to well and facility reclamation costs; ${ }^{40}$

- $\quad$ an increase to facility abandonment cost parameters for each well equivalent from $\$ 10,000$ to $\$ 17,000 ;{ }^{41}$

- a decrease in the industry average netback from a five year to a three year average, ${ }^{42}$ and

Directive 006, ibid, s 5; Redwater, supra note 2 at para 28.

Redwater, ibid.

Directive 006, supra note 13, s 6.

Ibid. s 5.

Redwater, supra note 2 at paras 25, 178; Redwater, ibid (Reply Brief of the Alberta Energy Regulator filed 9 December 2015 at para 10 [AER Brief]); Directive 006, ibid, Appendix 2. The amount required for a security deposit is calculated using the formulas found in Appendix 4 of Directive 006, ibid, which determines a licensee's LMR and LLR, with the deficiency being the amount required to return the same to 1.0 or above.

Directive 006, ibid, Appendix 2 (s 9).

Energy Resources Conservation Board, "Licensee Liability Rating (LLR) Program Changes and Implementation Plan," Bulletin: 2013-09 (Calgary: ERCB, 12 March 2013).

Ibid at 1 .

Ibid.

Ibid.

Ibid. 
- a change to the present value and salvage factor, increasing to 1.0 for all active facilities from 0.75 for active wells and 0.50 for active facilities. ${ }^{43}$

Overall, these changes to the LLR program resulted in a substantial increase to the amount certain E\&P companies were already required to post as security. These changes created a situation where E\&P companies were caught in a vicious cycle of committing increasing amounts of available cash flow to funding the security deposit requirements under Directive $006 .^{44}$ This significantly reduced the cash available to junior E\&P companies to fund capital expenditure programs, including drilling additional wells to increase production and maintain a positive $\mathrm{LMR}^{45}$

As a result, some junior E\&P companies were no longer able to comply with Directive 006 and faced enforcement by the AER under "Directive 019: AER Compliance Assurance. ${ }^{, 46}$ Enforcement by the AER included, among other things: non-compliance fees; partial or full suspension of operations; suspension or cancellation of permit, licence, or approval; and issuance of closure or abandonment. ${ }^{47}$ Many companies were forced to sell assets in order to comply with the new requirements.

Another effect of the amendments to Directive 006 in 2013 is that they helped the AER to dramatically reduce the province's exposure to abandonment and reclamation obligations. ${ }^{48}$ Significant funds were collected from E\&P companies and held in trust, pending either an increase in the LMR of those companies or, in the event of failure, to be available to satisfy the abandonment and reclamation obligations of those companies. ${ }^{49}$

As of 5 November 2016, the AER has collected approximately \$224 million in security deposits from the licensees deemed most at risk of defaulting on their environmental obligations in order to ensure that those licensees' obligations will be satisfied. ${ }^{50}$ The $\$ 224$ million in security held in trust by the AER is in addition to the amounts levied every year for the Orphan Fund. If the OWA is required to perform abandonment and reclamation work for an at risk licensee who has posted security, it is able to access the security deposit held by the AER in order to fund that work. ${ }^{51}$

When a licensee is deemed "defunct," any non-facility-specific LMR security deposit it posted would be used to address its unfunded suspension, abandonment, remediation, or reclamation liability as calculated in each program in which it participates. ${ }^{52}$ Any facilityspecific security deposit would first be applied to the specific facility, for which it was

$43 \quad$ Ibid.

Kelly Bourassa \& Ryan Zahara, "Increases to Alberta Licensee Liability Rating Program" (30 September 2013), Blakes Bulletin, online: <www.blakes.com/English/Resources/Bulletins/Pages/ Details.aspx?BulletinID $=1811>$.

Ibid.

Alberta Energy Regulator, “Compliance Assurance,” Directive 019 (Calgary: AER, 1 September 2010).

Ibid.

Alberta Energy Regulator, "Liability Management Programs Results Report," (Calgary: AER, 2 July 2016), online: <www.aer.ca/data/facilities/LMR 201607.pdf $>$ [AER July Report]. The current monthly AER Liability Management Programs Results Report can be found online: <www.aer.ca/data/facilities/ LLR Report 07.pdf $>$.

Ibid.

Ibid.

2014/15 Annual Report, supra note 18 at 38.

Directive 006, supra note 13, s 7.1. 
collected, with any surplus being available for any unfunded, non-site-specific liability of the licensee in question. ${ }^{53}$ The AER's requirements with respect to the form, use, and refund of security deposits provided under a liability management program are found in "Directive 068: ERCB Security Deposits." 54

\section{Abandonment And the Orphan Process}

Prior to 1997, all of the legal authority for abandonment of orphan wells was held by the Board. ${ }^{55}$ In 1997, the provincial legislation was broadened to grant the Board additional authority to conduct orphan activities, and it did so under the guise of the Alberta orphan program. ${ }^{56}$ The OWA began operation in 2002 and its current authority is now derived from the AER's delegation of certain of its powers, duties, and functions by way of the Orphan Fund Delegated Administration Regulation. ${ }^{57}$ There is also a memorandum of understanding (the MOU) between the AER, Alberta Environment and Sustainable Resource Development, and the OWA, which further delineates the roles and responsibilities between the AER and the OWA with respect to Orphan Fund matters. ${ }^{58}$

Pursuant to the Orphan Fund Delegated Administration Regulation and the MOU, the Orphan Fund is administered by the OWA ${ }^{59}$ The AER operates as the enforcement arm of the OWA under the OGCA. ${ }^{60}$ It also controls the designation and assignment of orphan properties to the OWA. ${ }^{61}$

A well, facility, or pipeline in the LLR program is eligible to be declared an orphan when the licensee of that licence becomes insolvent or "defunct." ${ }^{2}$ Under the common law, a debtor is considered insolvent if it meets the definition of an "insolvent person" in section 2 of the BIA, or if it meets the more lenient definition of "insolvent" as described in Stelco. ${ }^{63}$

Under the BIA, a licensee will be considered to be an "insolvent person" where it: (1) is unable to meet its obligations as they generally become due for any reason; (2) has ceased

Directive 006, ibid. CAPP also made submissions, confirmed by the AER, to the effect that when the AER takes a security deposit from a licensee, it is impressed with a trust, and funds are used for that licensee only, to serve towards their reclamation and abandonment obligations: Transcript, supra note 7 at 95 (lines 16-20).

54 Alberta Energy Regulator, "ERCB Security Deposits,” Directive 068 (Calgary: AER, 17 September 2010).

2014/15 Annual Report, supra note 18 at 2.

Ibid at 4.

Orphan Fund Delegated Administration Regulation, Alta Reg 45/2001, s 3 [Orphan Fund Delegated Administration Regulation].

2014/15 Annual Report, supra note 18 at 2.

See also OGCA, supra note 4, ss 70(1), 70(2).

Transcript, supra note 7 at 91 (lines 21-32); OGCA, ibid, ss 30(5), 72, 100(3).

2014/15 Annual Report, supra note 18 at 2.

The OWA recognizes that "Defunct Companies are licensees that are deemed defaulting working interest participants by the AER pursuant to Section 70(2)(b)(iii) of the Oil and Gas Conservation Act" which deals with defaulting working interest participants: OWA, "List of Defunct Companies," Orphan Well Association, online: <www.orphanwell.ca/pg defunct company list.html >. Generally, a licensee will be considered a "defaulting working interest participant" where it: (i) has an obligation under the OGCA to contribute toward suspension costs, abandonment costs, or related reclamation costs; (ii) has not contributed to those costs as required by the OGCA; and (iii) in the opinion of the AER, does not exist, cannot be located, or does not have the financial means to contribute to those costs: OGCA, supra note 4, s 70(2)(b).

63 Stelco Inc, Re (2004), 48 CBR (4th) 299 at para 26 (Ont SC), Farley J [Stelco]; Target Canada Co, Re, 2015 ONSC 303, 22 CBR (6th) 323 at para 26, Morawetz J. 
paying its current obligations in the ordinary course of business as they generally become due; or (3) would not have sufficient property to enable payment of all its obligations that are due. ${ }^{64}$ This definition also includes a corporation who is "reasonably expected to run out of liquidity within [a] reasonable proximity of time as compared with the time reasonably required to implement a restructuring." 65

However, it is the AER's practice to refuse to designate properties orphan until the licensee meets its definition of "insolvent," which only occurs where an insolvency professional appointed over the licensee has been discharged. ${ }^{66}$ Since insolvency is generally a criterion of the test to appoint an insolvency professional, the AER's approach is based on a tenuous interpretation of the OGCA. ${ }^{67}$

Once the AER determines that a well, facility, or pipeline meets the criteria outlined in section 70(2) of the OGCA, it will typically designate it an orphan. ${ }^{68}$ The OWA then becomes responsible for the abandonment and remediation of the property. The AER imposes stringent requirements on licensees before it will designate a property an orphan. Its position has generally been that this option is only available where the insolvent company has no ability to look after the licenced properties. ${ }^{69}$

The OWA will only abandon properties that have been properly designated "orphans" by the AER pursuant to section 70(2) of the OGCA and an insolvent party cannot submit properties to the OWA directly. ${ }^{70}$ Once an orphan designation has occurred, the OWA is obligated to take possession and control of the orphan property. ${ }^{71}$ The OWA then prioritizes abandonment of orphans in its inventory on a risk assessment matrix. ${ }^{72}$ The OWA has no direct role in value recovery or enforcement, as it does not have the ability to sell any orphan properties other than certain equipment located on the sites. ${ }^{73}$

The AER also has the ability to conduct abandonment and reclamation of properties on occasion. In fact, between 2013 and 2014, the AER actually abandoned 50 percent more wells than the OWA. ${ }^{74}$ This disparity between the AER's and OWA's effectiveness indicates that the roles between the two parties may still need further clarification in spite of the changes made in 2012 which were intended to "speed up the turnover of orphan properties to the OWA." 75 As a specialized body, the OWA should be provided with more authority to

Pursuant to the definition of "insolvent person" in the BIA, supra note 1, the licensee must also carry on business or have property in Canada, not be bankrupt, and have more than one thousand dollars in liabilities (ibid, s 2).

Stelco, supra note 63 at para 26.

Transcript, supra note 7 at 5 (lines 7-10).

Redwater, supra note 2 at para 167 . The Court found that the AER's interpretation of "insolvent" differs from the general or common law understanding of insolvency.

2014/15 Annual Report, supra note 18 at 2-3.

Redwater, supra note 2 at para 49.

2014/15 Annual Report, supra note 18 at 2-3. The OWA's annual report indicates that the designation process occurs through the issuance of an AER memorandum to the OWA.

Transcript, supra note 7 at 90 (lines 19-21). This statement indicates that the OWA is under the impression that possession is mandatory after designation.

2014/15 Annual Report, supra note 18 at 25.

Ibid at 38 .

Redwater, supra note 2 at para 80.

2014/15 Annual Report, supra note 18 at 3. 
manage the orphaning and abandonment process in order to streamline its operation and control its inventory.

\section{E. The Status of Abandonment Obligations in Alberta}

The procedural and historical context provided above is important to consider in light of the test set out by the Supreme Court of Canada in AbitibiBowater for determining whether environmental obligations are financial or regulatory claims. Financial claims are stayed and can be compromised in insolvency proceedings while regulatory claims cannot. ${ }^{76}$ In AbitibiBowater, the Supreme Court set out the test to determine whether a regulatory order, not framed in monetary terms, can constitute a "provable claim.",77

Prior to the release of AbitibiBowater, Panamericana was the leading decision in Alberta when it came to determining the priority of environmental liabilities in insolvency proceedings. ${ }^{78}$ The Alberta Court of Appeal in that case held that the abandonment of wells is an expense inherent in the nature of the oil and gas industry and, the moment a well is drilled, a licensee necessarily incurs environmental liability. ${ }^{79}$

The principle arising out of the Panamericana decision was simply that a public officer or public authority, who was statutorily required to enforce a public law, did not become a creditor of the person bound by such law. Generally, any obligations arising from the operation of, or compliance with, environmental legislation were owed to the public rather than the individual regulator. ${ }^{80}$

In the authors' view, the AER has relied heavily upon the reasoning in Panamericana in the development of its enforcement policies in the context of insolvency. ${ }^{81}$ However, Panamericana was decided on a unique set of facts not commonly replicated, and much of what was determined has since been supplanted by subsequent amendments to the BIA and the decision of the Supreme Court of Canada in AbitibiBowater. ${ }^{82}$ In particular, the decision in Panamericana was reached on the basis that:

(1) the receiver/manager had complete control of the wells for over three years, had operating control of them, and was not entitled to disclaim the wells; ${ }^{83}$

The BIA broadly defines "provable clai under the BIA by a creditor: BIA, supra note 1, s 2. Section 121(1) states that "[a]11 debts and liabilities, present or future, to which the bankrupt is subject on the day on which the bankrupt becomes bankrupt or to which the bankrupt may become subject before the bankrupt's discharge by reason of any obligation incurred before the day on which the bankrupt becomes bankrupt shall be deemed to be claims provable in proceedings under this Act" and section 121(2) considers that contingent and unliquidated claims can also be "provable claims" in certain circumstances [emphasis added]. Panamericana de Bienes y Servicios SA v Northern Badger Oil \& Gas Ltd, 1991 ABCA 181, 81 DLR (4th) 280, Laycraft CJ [Panamericana].

Ibid at 290.

Ibid.

Transcript, supra note 7 at 7 (lines 16-28) indicates that up to the release of the Redwater decision, it was the AER's view that the principles set out in Panamericana continue to be the law in Alberta.

Redwater, supra note 2 at paras 118-20.

Panamericana, supra note 77 at 297. 
(2) the receiver/manager in that case had generated revenue from the operation of the very properties it sought to renounce, ${ }^{84}$

(3) the receiver/manager had sold all of the assets of Northern Badger Oil and Gas Limited (Northern Badger) but seven wells had been "returned" by the purchaser to the receiver/manager and it proposed to renounce its interest in those wells $;{ }^{85}$ and

(4) the receiver/manager was holding sales proceeds in the amount of approximately $\$ 226,000$ from the sale of the assets of Northern Badger, and the abandonment and reclamation costs it was seeking to avoid were in the approximate amount of $\$ 202,500$, of which $\$ 17,330$ was Northern Badger's share. ${ }^{86}$

Additionally, when Panamericana was decided, section 14.06(1.2) of the BIA, which provides protection to receivers and trustees, was not in force.

The most recent application of the Panamericana principle was in Strathcona, where Justice Burrows held that a trustee was required to use estate assets to comply with the bankrupt's statutorily imposed obligation to meet public safety and environmental standards notwithstanding resulting prejudice to any creditors. ${ }^{87}$

The Strathcona decision dealt with a trustee's obligation to use assets of the estate to comply with the bankrupt's requirement to provide an approved drainage system on the land where a condominium development was built. ${ }^{88}$ The obligation to act in that case was also imposed by statute. The Alberta Court of Queen's Bench held that the Panamericana principle applied and required the trustee to comply with the bankrupt's obligations. ${ }^{89}$

There was little consideration of the application of section 14.06(4) of the BIA "which gives the Trustee the right in certain circumstances to avoid personal liability for failure to comply with an order requiring a Trustee to remedy an environmental condition by abandoning the property." 90 The Alberta Court of Queen's Bench made no finding on the application of section 14.06(4) in Strathcona. ${ }^{91}$

Whether or not the court-appointed receiver and trustee (Receiver/Trustee), could disclaim certain properties, licences, and associated abandonment obligations was a main point of contention in the Redwater proceedings. ${ }^{92}$ In the authors' opinion, without extensive consideration of section 14.06(4), and in light of the recent decision in Redwater, the decision of the Court in Strathcona holds little precedential value. ${ }^{93}$

Ibid at 298 .

Ibid at 284

Ibid at 285-86.

Strathcona (County) v Fantasy Construction Ltd (Trustee of), 2005 ABQB 559, 256 DLR (4th) 536 at para 37, Burrows J [Strathcona].

Ibid at para 44

Ibid at para 51

Ibid at para 61.

Ibid.

Transcript, supra note 7 at 15 (lines 32-41), 30 (lines 1-12); Redwater, supra note 2 at para 134. The AER has acknowledged that it is of the view that abandonment obligations of a licensee are tied to its AER licences.

93 Redwater, ibid at paras 126-29. 
In AbitibiBowater, AbitibiBowater Inc. (AbitibiBowater) was experiencing financial pressure and filed for insolvency protection in Canada and the United States. ${ }^{94}$ After AbitibiBowater entered into CCAA proceedings, the Province of Newfoundland and Labrador (the Province) issued a number of environmental orders against it which required remediation action plans to be submitted for five specific areas used as industrial sites. ${ }^{95}$ Three of the five sites to which the orders were directed had also been expropriated by the Province. ${ }^{96}$

The Province brought an application declaring that AbitibiBowater's claims procedure could not bar it from enforcing its regulatory orders. ${ }^{97}$ It argued that the regulatory orders were not provable claims in the context of insolvency legislation and therefore the claims procedure did not, and could not, apply. ${ }^{98}$ The argument advanced by the Province in support of its position was that it was acting solely in its role as regulator to enforce a public duty in an attempt to hold a corporate debtor responsible for its abandonment and reclamation obligations. ${ }^{99}$ The Supreme Court of Canada rejected the Province's reasoning, stating:

This objection demonstrates a misunderstanding of the nature of insolvency proceedings. Subjecting an order to the claims process does not extinguish the debtor's environmental obligations any more than subjecting any creditor's claim to that process extinguishes the debtor's obligation to pay its debts. It merely ensures that the creditor's claim will be paid in accordance with insolvency legislation. Moreover, full compliance with orders that are found to be monetary in nature would shift the costs of remediation to third-party creditors, including involuntary creditors, such as those whose claims lie in tort or in the law of extra-contractual liability. In the insolvency context, the Province's position would result not only in a super-priority, but in the acceptance of a "third-party-pay" principle in place of the polluter-pay principle. ${ }^{100}$

Additionally, in clarifying the priority of environmental obligations in insolvency proceedings, the Supreme Court of Canada rejected the reasoning in Panamericana:

The first answer to the Province's argument is that courts have never shied away from putting substance ahead of form. They can determine whether the order is in substance monetary.

The second answer is that the provisions relating to the assessment of claims, particularly those governing contingent claims, contemplate instances in which the quantum is not yet established when the claims are filed. Whether, in the regulatory context, an obligation always entails the existence of a correlative right has been discussed by a number of scholars. Various theories of rights have been put forward. However, because the Province issued the orders in this case, it would be recognized as a creditor in respect of a right no matter which of these theories was applied. As interesting as the discussion may be, therefore, I do not need to consider which theory should prevail. The real question is not to whom the obligation is owed, as this question is answered by the statute, which determines who can require that it be discharged. Rather, the question is whether it is sufficiently certain that the regulatory body will perform the remediation work and, as a result, have a monetary claim.

Supra note 3 at para 7 .

Ibid at para 9.

Ibid.

Ibid at para 10 .

Ibid.

Ibid.

Ibid at para 40 [emphasis added]. 
The third answer to the Province's argument is that insolvency legislation has evolved considerably over the two decades since Panamericana. At the time of Panamericana, none of the provisions relating to environmental liabilities were in force. ${ }^{101}$

Not only did the Supreme Court of Canada expressly recognize that environmental orders could be caught by the definition of "claims," but more importantly, it held that environmental orders that were claims could be compromised in insolvency proceedings. ${ }^{102}$ This overarching principle was captured by the Supreme Court of Canada where it stated:

\begin{abstract}
What the Province is actually arguing is that courts should consider the form of an order rather than its substance. I see no reason why the Province's choice of order should not be scrutinized to determine whether the form chosen is consistent with the order's true purpose as revealed by the Province's own actions. If the Province's actions indicate that, in substance, it is asserting a provable claim within the meaning of federal legislation, then that claim can be subjected to the insolvency process. Environmental claims do not have a higher priority than is provided for in the CCAA. Considering substance over form prevents a regulatory body from artificially creating a priority higher than the one conferred on the claim by federal legislation. This Court recognized long ago that a province cannot disturb the priority scheme established by the federal insolvency legislation (Husky Oil Operations Ltd. v. Minister of National Revenue, [1995] 3 S.C.R. 453). Environmental claims are given a specific, and limited, priority under the CCAA. To exempt orders which are in fact monetary claims from the CCAA proceedings would amount to conferring upon provinces a priority higher than the one provided for in the CCAA. ${ }^{103}$
\end{abstract}

As a result, the Supreme Court set out the test for when a regulatory order will constitute a provable claim: (1) where a debt, liability, or obligation is owed to a creditor; (2) the debt, liability, or obligation is incurred before bankruptcy; and (3) there is sufficient certainty that the regulatory order will eventually result in a monetary claim. ${ }^{104}$

In the majority's reasons, Justice Deschamps set out a number of factors to be considered in determining whether it is sufficiently certain that a regulator's order will constitute a provable claim, including:

(1) whether the activities are ongoing;

(2) whether the debtor is in control of the property;

(3) whether the debtor has the means to comply with the order; and

(4) the effect that requiring the debtor to comply with the order would have on the insolvency process. ${ }^{105}$

The result was a determination that courts should look behind the stated intentions and examine the substance and effect of such orders to determine whether they may constitute

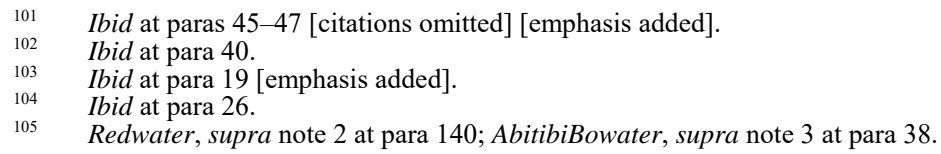


a provable claim. There is relatively little dispute over the first two points in most cases. However, issues commonly arise when attempting to determine whether it is sufficiently certain that a regulatory body will conduct the work necessary to crystallize a monetary claim. In the context of insolvency, it is the authors' view that many regulatory orders currently issued by provincial regulators may in fact constitute provable claims and be subject to, and compromised in, the respective claims process.

\section{F. Application in the RedWater Proceedings}

An example of the disputed priority of provincial regulator claims in insolvency proceedings was evidenced in the receivership and bankruptcy proceedings of Redwater Energy Corporation (Redwater). ${ }^{106}$ Redwater was a publicly listed junior oil and gas corporation with significant oil and gas properties located in Alberta. Redwater was also a licensee pursuant to the OGCA and $P A$ in respect of a number of those properties. It began experiencing financial difficulty after a number of events left it unable to service its debt and, as a result, Redwater and the Lender negotiated an amended loan agreement which required it to carry out a sales process in an attempt to repay the outstanding loan amounts. ${ }^{107}$

The sale process was unsuccessful and Redwater's primary secured creditor issued a demand for full repayment of the loan and issued a notice of intention to enforce security. Redwater was unable to raise sufficient funds and a receiver was initially appointed over its assets. Redwater was subsequently assigned into bankruptcy in October 2015.

Redwater was in possession of approximately 130 AER-licenced wells, facilities, and pipeline segments at the time the receivership order was granted. Many of Redwater's assets were shut-in, although most still required some form of environmental remediation or abandonment. Redwater's LMR prior to receivership was 1.06 and during its insolvency proceedings it had dropped to 0.69 as of 4 June $2016 .{ }^{108}$ Redwater had not posted any security with the AER in respect of its abandonment and reclamation obligations.

In June 2015, the AER asked the Receiver/Trustee, in its capacity as receiver, for confirmation that it was in possession and control of all of Redwater's assets before the AER would consider a licence transfer application in relation to a proposed sale of assets. ${ }^{109} \mathrm{In}$ July 2015, the Receiver/Trustee advised the AER that, in accordance with paragraph 3(a) of its Receivership Order, the Receiver/Trustee would only take possession and control of approximately 20 of the 127 AER licenced properties. ${ }^{110}$ The Receiver/Trustee alleged that it either never took possession of, or it disclaimed, the remaining licenced properties (the Renounced Assets). After Redwater's assignment into bankruptcy, the Receiver/Trustee further disclaimed the Renounced Assets, in its capacity as trustee, in November $2015 .{ }^{111}$

106 Redwater, ibid

107 See ibid (Receiver's first report in dated 21 July 2015 at 5-6); ibid (Receiver's second report dated 3 October 2015 at 5-23).

108 Redwater, ibid at para 31; Alberta Energy Regulator, "Liability Management Programs Results Report" (Calgary: AER, 4 June 2016), online: <www.aer.ca/data/facilities/LLR_201606.pdf>.

Redwater, ibid at para 21.

Ibid at para 22.

Ibid at para 24 . 
Upon learning that the Receiver/Trustee did not intend to take possession of the Renounced Assets, the AER issued two rounds of abandonment orders (the Abandonment Orders) against Redwater in July and August 2015. The Abandonment Orders required Redwater, as licensee, to abandon the Renounced Assets either immediately where it was the sole working interest participant (WIP) or by September 2015 where it was not the sole WIP. The AER indicated in the Abandonment Orders that it would "use its process to have the properties abandoned" in the event that Redwater did not do so. ${ }^{12}$ The AER also indicated that it would "exercise all remedies available to it to recover costs from the liable parties" resulting from enforcing the Abandonment Orders. ${ }^{113}$

Similar to AbitibiBowater, one of the main issues in Redwater was whether the Abandonment Orders constituted monetary claims and whether the AER could obtain priority over other creditors to any sale proceeds through the exercise of its regulatory power. ${ }^{114}$ The AER and the OWA both argued that the Abandonment Orders did not constitute a debt owing to the provincial regulator and, alternatively, even if they could be construed to constitute a financial obligation, there was no evidence to suggest that the AER would ever advance a claim for repayment. ${ }^{115}$

The written decision of Chief Justice Wittmann primarily dealt with two issues: (1) whether provincial oil and gas licensing legislation could prevent the Receiver/Trustee from abandoning both the Renounced Assets and the accompanying liability, and (2) whether the same legislation could require that the Receiver/Trustee expend funds from Redwater's estate to comply with the Abandonment Orders as a condition precedent to the AER approving a transfer of Redwater's AER licences. Whether or not the Abandonment Orders constituted provable claims was integral to the second issue.

\section{G. Disclaiming The RenOUnCED ASSETS}

The Renounced Assets could have been declared orphans in accordance with sections $70(2)$ of the OGCA and the renunciation issue would never have arose. The AER's interpretation of the OGCA and the $P A$ required that the constitutionality of the Receiver/Trustee's ability to disclaim the Renounced Assets be determined. The Alberta Court of Queen's Bench found that the provincial legislation that the AER relied upon to require the Receiver/Trustee to comply with the Abandonment Orders and include the Renounced Assets in the calculation of Redwater's LMR conflicted with the BIA and triggered the doctrine of federal paramountcy. ${ }^{116}$

The AER and the OWA argued that allowing a court-appointed receiver or trustee to refuse to take possession of an insolvent debtor's AER-licenced properties would amount to allowing an insolvent licensee to disregard provincial statutory requirements. ${ }^{117}$ The AER

Ibid at para 23 .

Ibid.

Ibid at para 6.

Transcript, supra note 7 at 19 (lines 10-16), 26 (lines 11-19); Redwater, supra note 2 at para 62.

Redwater, ibid at para 180.

Ibid at para 42 . 
also argued that the ability of the Receiver/Trustee to disclaim property was limited to circumstances where it would be personally liable for environmental damage. ${ }^{118}$

Both the AER and the Attorney General of Alberta argued that the Receiver/Trustee's ability to disclaim property is limited to real property. Specifically, the AER argued that

one cannot ignore the wording "real property" specifically used by Parliament in section 14.06 of the BIA. The AER also refers to section 14.06(7) and notes that the super priority only applies against the land. The AER's position is that a licence is personal property, not real property. For instance, the Trustee could disclaim the lease, but not a licence. The AER says that the obligation to abandon is only with the licensee and not the real property. The AER argues that what can be renounced under section 14.06 of the BIA is the real property that has been remediated. ${ }^{119}$

The Court found the issuance of the Abandonment Orders entitled the Receiver/Trustee to exercise its right to disclaim property under section 14.06(4) of the $B I A$, which states:

(4) Notwithstanding anything in any federal or provincial law but subject to subsection (2), where an order is made which has the effect of requiring a trustee to remedy any environmental condition or environmental damage affecting property involved in a bankruptcy, proposal or receivership, the trustee is not personally liable for failure to comply with the order, and is not personally liable for any costs that are or would be incurred by any person in carrying out the terms of the order,

(a) if, within such time as is specified in the order, within ten days after the order is made if no time is so specified, within ten days after the appointment of the trustee, if the order is in effect when the trustee is appointed, or during the period of the stay referred to in paragraph (b), the trustee

(ii) on notice to the person who issued the order, abandons, disposes of or otherwise releases any interest in any real property, or any right in any immovable, affected by the condition or damage;

(c) if the trustee had, before the order was made, abandoned or renounced or been divested of any interest in any real property, or any right in any immovable, affected by the condition or damage. $^{120}$

The AER's Abandonment Orders were found to constitute orders "which [had] the effect of requiring a trustee to remedy any environmental condition or environmental damage affecting property involved in a bankruptcy, proposal or receivership."121 The Court found

120 BIA, supra note $1, \mathrm{~s} 14.06(4)$ [emphasis added]. The reference to a trustee in section 14.06 also includes a court-appointed receiver pursuant to section $14.06(1.1)$. 
that the Receiver/Trustee had the ability to disclaim the Renounced Assets after determining that it was in the estate's best interest to do so. ${ }^{122}$

The Receiver/Trustee, in its capacity as Receiver, was entitled to disclaim the Renounced Assets by advising the AER it was doing so pursuant to paragraph 3(a) of the Receivership Order. ${ }^{123}$ The Court deemed that, after the time of appointment, a receiver is entitled to choose which assets it will take possession of and control. ${ }^{124}$ However, pursuant to section 71 of the BIA, all of the assets of Redwater were vested in the Receiver/Trustee, in its capacity as trustee, upon the bankruptcy order being proclaimed. ${ }^{125}$ Therefore, the Receiver/Trustee was required to rely on section 14.06(4) to disclaim the Renounced Assets.

Chief Justice Wittmann held that there was a clear operational conflict between section $14.06(4)$ of the BIA, which expressly allows "any interest in any real property" to be disclaimed when the statutory requirements of the section are met, and the provincial OGCA and $P A$, which did not contain any corresponding mechanism for disclaimer. ${ }^{126}$ Dual compliance with both pieces of legislation was found to be impossible where the Receiver/Trustee exercised its rights under the BIA but remained liable under the OGCA and the $P A .^{127}$

The exercise of the Receiver/Trustee's "BIA renouncement rights" under section 14.06(4) was not limited to real property but included any interest in real property. ${ }^{128}$ The Court found that Panamericana made it clear a licence "is tied to real property and abandonment orders only make sense if they attach to real property. The abandonment obligations flow out of the licence regime, but the abandonment orders attach to real property." 129 Thus, a licence was held to constitute an interest in real property.

The Court found that the statutory definition of licensee under section 1(1)(cc) of the OGCA and 1(1)(n) of the PA also frustrated the purpose of sections 14.06(4)(a)(ii) and $14.06(4)(c)$ of the BIA by "effectively preventing the Trustee from renouncing licensed assets, which provide no economic benefit to the creditors" $" 130$ and by requiring the Receiver/Trustee to assume all compliance obligations in respect of the Renounced Assets, which would put the Receiver/Trustee at "personal financial risk." 131 As a result, the Court held as follows:

In the result, the Trustee is not a licensee of the renounced assets, ought not to be required to assume any liabilities, and is not bound by the Abandonment Orders relating to the renounced assets in seeking approval of the sales process to market and sell the assets remaining under its possession and control of. In other words, so long as the Trustee renounces the affected property in accordance with section 14.06(4), the AER

Ibid at paras 129,150 .

The wording in section 3(a) of the Receivership Order appointing Grant Thornton Limited over the property of Redwater followed the wording in section 3(a) of the Alberta Template Receivership Order (ibid at paras 13, 15).

Ibid at para 150 .

Ibid at para 154 .

Ibid at paras $155-56$.

Ibid at para 155 .

Ibid at para 134 .

Ibid.

Ibid at para 182

Ibid. 
cannot attempt to impose on the Trustee the obligation to remediate the renounced property by performance or posting security. In addition, the effect of section 1 of the OGCA and the Pipeline Act is to remove the benefits otherwise available in a renunciation and thus frustrates the purpose of section 14.06 of the BIA. Despite renouncing, a receiver would have to assume control of the remediation activities and incur the very risks that section 14.06 of the BIA is designed to avoid, which may lead to trustees refusing mandates where there are potential liabilities if they have to comply with abandonment orders. ${ }^{132}$

In the authors' opinion, this holding simply clarified the interpretation of section 14.06(4) of the BIA as it has been traditionally understood and applied it to the factual circumstances regarding oil and gas licenced properties. The Court did not create new law in Redwater. Simply put, it is clear that court-appointed receivers and trustees are entitled to disclaim AER-licenced assets and the corresponding licences, liabilities, and obligations, as long as the statutory requirements of section 14.06 have been met.

\section{H. The Abandonment ORders are Provable Claims}

The second issue in Redwater addressed whether the AER's Abandonment Orders could require that the Receiver/Trustee expend funds from Redwater's estate (1) as costs of administration of the estate in respect of the Renounced Assets, and (2) as a condition precedent to the AER approving a transfer of Redwater's licences. On both counts, the Court found that the Abandonment Orders were provable claims and that the AER's actions frustrated the purpose of section 14.06(4)(a)(ii) and (c) of the BIA. ${ }^{133}$

The AER took the position that the Abandonment Orders did not require the payment of funds but rather required a licensee to take specific action in respect of the Renounced Assets. It argued that it does not regularly take action in respect of orphaned properties and had no intention of doing so with respect to the Renounced Assets, in spite of evidence to the contrary. ${ }^{134}$ In the alternative, the AER argued that even if it were to abandon the Renounced Assets, it would not advance a claim for the work and thus would not meet the third element of the AbitibiBowater test requiring both the crystallization and the advancement of a monetary claim. ${ }^{135}$

The AER argued that the third element was critical because it established that the AER did not and would not seek recovery for the costs of abandonment. ${ }^{136}$ It admitted that there would be monetary consequences arising out of the Abandonment Orders but since the AER was not seeking reimbursement, it would not meet the requirement of crystalizing and advancing a monetary claim. ${ }^{137}$

The OWA took the position that the obligations imposed on Redwater by the Abandonment Orders were not monetary claims but were regulatory in nature. ${ }^{138}$ Further, it

Ibid at para 156 [emphasis added].

Ibid at para 181 .

Ibid at paras 49,63 .

Ibid at para 49.

Ibid at para 164 .

Ibid at para 165 .

Ibid at para 61 . 
submitted that "the meaning of section 14.06(6) and 'claims for' is that a third party, such as the government or a working interest owner, cannot bring a claim against a trustee for the costs of remedying property that is renounced and ask a trustee or court to have that claim rank as a cost of administration." 139

Additionally, it argued that if the Abandonment Orders did amount to a claim, there was insufficient certainty that the orders would be enforced. ${ }^{140}$

The first and second steps of the AbitibiBowater test were clearly met on the facts and were conceded by the AER. ${ }^{141}$ The third part of the AbitibiBowater test asks whether it is possible to attach a monetary value to obligations imposed on Redwater by the Abandonment Orders. ${ }^{142}$ The main factors considered were whether it was sufficiently certain that the AER or the OWA would (1) perform the obligations contemplated by the Abandonment Orders, and (2) assert a monetary claim to have its costs reimbursed. ${ }^{143}$ The Court found several factors that indicated that either the AER or the OWA would complete the work and advance a claim, including:

(a) once the AER designates a property an orphan, then the OWA will perform the work; ${ }^{144}$

(b) the AER has the power to conduct abandonment and reclamation of the Renounced Assets themselves; ${ }^{145}$

(c) the AER expressly stated in correspondence that it would seek reimbursement of the costs of abandonment of the Renounced Assets; ${ }^{146}$

(d) the OWA can seek reimbursement from the AER for abandonment costs where it holds a deposit; ${ }^{147}$

(e) the Receiver/Trustee was not in possession of the Renounced Assets and had no ability to perform the work required by the Abandonment Orders; ${ }^{148}$

(f) there was no evidence that Redwater would ever be reorganized or that any activities would continue in respect of the Renounced Assets; ${ }^{149}$

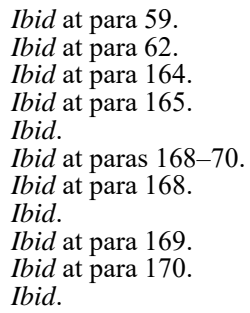


(g) there was no current or subsequent owner for the Renounced Assets, a subsequent purchaser of the Renounced Assets, or any other party who could be compelled to comply with the Abandonment Orders; ${ }^{150}$

(h) the Receiver/Trustee was of the opinion that no one would ever purchase the Renounced Assets; ${ }^{151}$ and

(i) there were only WIPs in respect of 20 percent of Redwater's assets and the AER had no "realistic alternatives to performing the remediation work itself other than deeming the renounced assets orphan wells." 152

The AER is required to initiate the orphaning process. Additionally, even in circumstances where the OWA performs the abandonment and reclamation of properties, the AER alone has the ability to enforce the payment of such costs as a debt owing to the Orphan Fund and it is treated the same as any other debt owing to the AER ${ }^{153}$ As a result, the Court found that the AER's claim for a security deposit or compliance constituted a provable claim. ${ }^{154}$ The Court found that it was obligated to look at the substance and the effect of the Abandonment Orders on the Redwater proceedings and not simply strictly apply the AbitibiBowater test. ${ }^{155}$

Although the facts of Redwater did not meet the strict "sufficient certainty" criterion because it was unclear which of the AER or OWA would complete the abandonment of the Renounced Assets, the Court refused to apply a strict interpretation, instead citing the intention of the majority of the court in AbitibiBowater. ${ }^{156}$ If the Receiver/Trustee complied with the Abandonment Orders, it "would require the [Receiver/Trustee] to expend funds by way of security that would be used to perform the abandonment work." ${ }^{157}$ Furthermore, the Court went on to state:

\footnotetext{
The effect is that if the obligations to remediate property are fully complied with by the Trustee within this bankruptcy context, the claim of the Province for remediation costs will be given a super priority not provided for under section 14.06. The creditors deprived of the usual order of priority in bankruptcy will be subject to a "third-party-pay" principle in place of the "polluter-pay" principle. The history of amendments to the BIA in this case shows that Parliament intended that the priority of creditors as provided under section 14.06, and thus the distribution of funds, ought not to be disturbed by provincial legislation. ${ }^{158}$
}

As a result, the Court found that the Abandonment Orders were "intrinsically financial" in nature, regardless of whether they expressly required the payment of money from Redwater's estate, and determined that the Abandonment Orders constituted a provable claim. ${ }^{159}$ As a provable claim, the AER's claim is subject to the single proceedings model

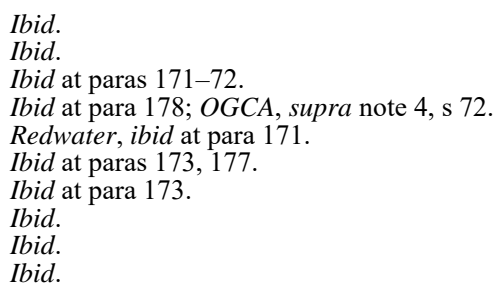


and the scheme of distribution provided for under the $B I A .{ }^{160}$ If given the priority proposed by the AER, the costs associated with the Abandonment Orders would directly affect the BIA scheme of distribution and thereby frustrate the primary purposes of the $B I A .{ }^{161}$ The Court applied the existing case law and came to a holding consistent with the previous jurisprudence in the area. ${ }^{162}$ Whether or not it is consistent with the sustainability of the Orphan Fund is a question better suited to legislators and one which may soon be addressed in light of Chief Justice Wittmann's decision.

\section{COSTS OF ADMINISTRATION}

Both the Receiver/Trustee and the Lender, as the primary secured creditor, argued that the AER did not have a priority claim to the sale proceeds for any abandonment and reclamation costs in respect of any of Redwater's licenced assets. ${ }^{163}$ Additionally, they argued that using the provincial licensing regime to require the posting of security or compliance with the Abandonment Orders would necessarily frustrate the priority given to environmental claims in the BIA.

The OWA advanced the position that, if the Receiver/Trustee conducted the abandonment of the Renounced Assets pursuant to the Abandonment Orders, there is nothing in the BIA which prevents the expenditure of funds from being characterized as costs of administration. ${ }^{164}$ It argued that the purpose of section 14.06(6), and the inclusion of "claims for," is intended to exclude only third party claims for the costs of remedying a property from ranking as costs of administration. ${ }^{165}$

In Moloney, ${ }^{166}$ Justice Gascon identified two purposes that were supported by certain provisions of the BIA: (1) the equitable distribution of the bankrupt's assets among his or her creditors, and (2) the bankrupt's financial rehabilitation. Both purposes were found to support Parliament's policy objective of maximizing the value of a debtor's assets through the use of insolvency legislation that recognizes existing creditor rights and establishes clear rules for ranking priority claims. ${ }^{167}$

The position of the AER and the OWA practically resulted in the costs of abandonment and reclamation being elevated to costs of administration, which frustrates the purposes of the BIA as outlined above. ${ }^{168}$ The Supreme Court of Canada in AbitibiBowater considered this very issue when analyzing the remediation work to be performed by the provincial environmental body in that case and said:

Parliament recognized that regulatory bodies sometimes have to perform remediation work (see House of Commons, Evidence of the Standing Committee on Industry, No. 16, 2nd Sess., 35th Parl., June 11, 1996).

When one does so, its claim with respect to remediation costs is subject to the insolvency process, but the

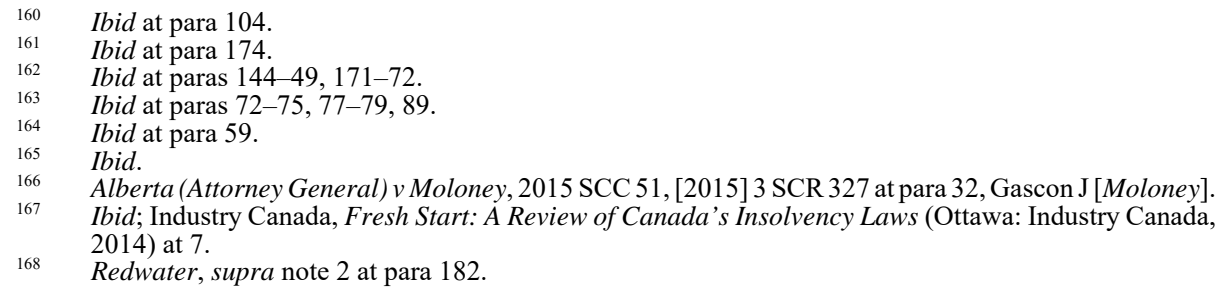


claim is secured by a charge on the contaminated real property and certain other related property and benefits from a priority (s. 11.8(8) CCAA). Thus, Parliament struck a balance between the public's interest in enforcing environmental regulations and the interest of third-party creditors in being treated equitably. ${ }^{169}$

As referenced in the quote above, a Parliamentary standing committee in 1996 (the Standing Committee) discussed proposed amendments to the BIA and considered the challenges faced by regulators and companies who have remediation obligations but are insolvent. The Standing Committee determined that the proposed amendments to section 14.06 properly balanced those considerations. The Standing Committee considered the priority to be accorded to regulators for such claims, and where that priority was insufficient to satisfy the obligations of the insolvent entity, the regulator was limited to having an ordinary claim against the remaining assets of the bankrupt. ${ }^{170}$

In Redwater, it was the Court's view that where an insolvency professional is obligated by way of a public duty under the general law to expend estate funds, such expenditure of funds remains subject to the provisions of the BIA, including section $14.06(6) .{ }^{171}$ Notably, the Court stated:

\footnotetext{
In this case, forcing a licensee to comply with the AER orders frustrates the purpose of section 14.06 in limiting the liability of receivers and trustees for the environmental condition of or environmental damage to property of the debtor. It also frustrates the BIA's purpose of equitable distribution of the assets. Under section 14.06, Parliament has expressly legislated with regards to priorities and claims concerning environmental orders by choosing to deal with the priority of claims for environmental remediation in subsections 14.06(6), 14.06(7) and 14.06(8) of the BIA. Had it been Parliament's intention that claims such as the AER claims in this case have priority over the rest of the creditors of the bankruptcy, it could have said so. Regarding section 14.06(6), I note that if the AER orders were enforceable in this case, the Trustee would be required to incur costs to remedy environmental damage or conditions as administration costs. This would frustrate section $14.06(6)$ of the BIA. ${ }^{172}$
}

By requiring the Receiver/Trustee to use funds of Redwater's estate to comply with the Abandonment Orders in respect of the Renounced Assets, the Court found that the purpose of the BIA was frustrated. ${ }^{173}$ Specifically, it found that the legislative purpose of sections $14.06(5),(6),(7)$, and (8) of BIA was frustrated, as the Receiver/Trustee was required to address the environmental claims regardless of whether the Renounced Assets had been abandoned under section 14.06(4). ${ }^{174}$

AbitibiBowater, supra note 3 at para 32 [emphasis added].

House of Commons Debates, 35th Parl, 2nd Sess, No 16 (11 June 1996) at 1545-55.

Redwater, supra note 2 at paras 132-33, 182.

Ibid at para 176 [emphasis added].

Ibid at para 182 .

Ibid. 
The AER's position necessarily required the Receiver/Trustee to expend estate funds to address obligations in respect of the Renounced Assets created by the Abandonment Orders, advancing the AER's claims to costs of administration under the BIA. ${ }^{175}$ The Court found that this position was inconsistent with the existing case law, and applied the doctrine of paramountcy to render the current licensing regime inoperative to the extent that it conflicted with the $B I A .^{176}$

\section{COMPLiANCE AS A CONDITION PRECEDENT TO A LICENCE TRANSFER}

The second issue that arose in Redwater was whether the AER could require the posting of a security deposit or compliance with the Abandonment Orders as a precondition to approving a licence transfer application brought by Redwater or the Receiver/Trustee. However, the Court found that doing so frustrated the legislative purpose of sections 14.06(5), (6), (7), and (8) of BIA by requiring compliance with the Abandonment Orders ahead of payment to Redwater's other creditors. ${ }^{177}$

The Receiver/Trustee and the Lender argued that the AER was attempting to use the requirements for the transfer of licences under Directive 006 to require the Receiver/Trustee to use estate assets to ensure that the AER's provable claim for abandonment and reclamation costs was satisfied ahead of all other creditors. ${ }^{178}$ In the absence of a positive LMR, the only way for the Receiver/Trustee to secure a transfer of licences was to use assets of the Redwater's estate to post security or abandon the Renounced Assets. ${ }^{179}$ This would have had the effect of preferring the unsecured claim of the AER over the claims of Redwater's other creditors.

The AER and OWA claimed that the purpose of the licensing regime was simply to ensure that the responsibility to comply with end of life obligations would be borne by the parties responsible. ${ }^{180}$ However, as advanced by the Lender in Redwater, it is the secured creditors of such companies who end up footing the bill. ${ }^{181}$ Such a substantive policy change would have an unsettling effect on lending to oil and gas companies as well as receivers or trustees of any companies who could be subjected to any kind of public duty to comply with environmental obligations. ${ }^{182}$

Where solvent parties are contemplating a transaction requiring a licence transfer application it must result in both parties having an LMR of 1.0 or above, unless security is posted. If either the transferor or transferee of a licence will have a post-transfer LMR below 1.0, the AER will require a security deposit in an amount representing the LMR deficiency prior to approving the transfer. ${ }^{183}$ In a receivership or bankruptcy, the AER may relax this requirement in order to facilitate sales of licenced assets. The AER's practice has been to

Ibid.

Ibid at para 183 .

Ibid at para 182 .

Ibid at paras 5,73 .

Ibid at para 30.

Ibid at paras 40,51 .

Ibid at para 173 .

Transcript, supra note 7 at 133 (lines 12-14).

AER Brief, supra note 36 at para 9 . 
permit sales and approve related licence transfers even where the seller's LMR is below 1.0, provided the net effect of the transaction will not worsen the insolvent seller's LMR. ${ }^{184}$ There was no option available to the Receiver/Trustee to maintain Redwater's LMR and conduct a sale without paying out the AER's claim.

The AER's statutory discretion to deny licence transfers based on a failure to provide security deposits and require compliance with regulatory orders was found by the Court to frustrate the purposes of the $B I A{ }^{185}$ The Court found that the AER's claim was not entitled to statutory super priority in this case and that the requirement to post security or comply with the Abandonment Orders would frustrate the legislative purpose of sections 14.06(5), (6), (7), and (8) of BIA by requiring the expenditure of estate funds ahead of distribution to Redwater's other creditors. ${ }^{186}$

The Court reaffirmed its role as being limited to one of applying legislation, not creating policy. ${ }^{187}$ The Court found that Parliament had weighed competing considerations and only provided a super priority in certain limited circumstances. ${ }^{188}$ Only if the AER, or the OWA, abandons and reclaims assets, does section 14.06(7) of the BIA grant the AER statutory security in priority to "any other claim, right, charge or security against the property" and only in respect of the affected property or property contiguous to the affected property. Since the AER had not met the statutory requirements, its claim was not entitled to super priority status.

Moreover, from a policy standpoint, allowing the AER's claim for abandonment and reclamation obligations to take priority over a registered and perfected secured charge of a lender would create significant concerns in an already depressed energy market, especially where there is no way for lenders to take any kind of precaution to mitigate their risk. Such an approach would vitiate the entire purpose of the BIA priority scheme under section 14.06 and likely curtail further investment into an already desperate sector.

After the release of Redwater, there may be changes to how the AER goes about enforcing licensee obligations in order to ensure the sustainability of the Orphan Fund. The authors hope that Redwater results in insolvent licensees' producing and viable wells being sold rather than orphaned as a result of the AER's refusal to transfer licences and the insolvency professional being forced to seek a discharge. Allowing the sale of producing assets may result in a decrease in the number of orphan properties and could provide the OWA an opportunity to address the backlog of orphaned properties. 


\section{MOVIng ForWARd PoST-REDWATER: Facilitating the Sale of E\&P Companies’' Assets}

\section{A. IMPLICATIONS OF REDWATER}

There are several possible outcomes and consequences of the ultimate resolution of Redwater's insolvency proceedings. The Redwater decision has now been appealed to the Alberta Court of Appeal by both the AER and the OWA. The appeal was heard on 11 October 2016, and as of submission for publication no decision has been released. It is unclear how far the parties may pursue the appeal of the Redwater proceedings; the final resolution may take several years. ${ }^{189}$

One possible outcome of the appeal is that the Redwater decision is upheld by the Court of Appeal. This would have the effect of requiring the AER to ignore the assets renounced by receivers and trustees when calculating an insolvent licensee's LMR in the context of a court-supervised sale process. It also would set a precedent allowing courts to direct the AER to transfer licences to purchasers in a court-supervised sale process notwithstanding its internal requirements for a licence transfer not being met.

The principles set out in Redwater will likely be of use to lenders in the interim and may curb some of the uncertainty present in the energy market. Since the release of Chief Justice Wittmann's decision, the authors are aware of cases of receivers being appointed with the specific power to disclaim and renounce properties of the debtor set out in the form of receivership order in accordance with the reasoning in Redwater. ${ }^{190}$

An important consequence is that the priority scheme, as understood by lenders and secured creditors, has been preserved. ${ }^{191}$ Had the Court accepted the AER's argument in this regard, the authors believe this would have had an immediate impact on how lenders considered abandonment and reclamation obligations of oil and gas companies. The lending value of assets of E\&P companies would have changed significantly, potentially further impairing the ability of E\&P companies to obtain credit or other funding.

Another possible outcome, if the Court of Appeal finds in favour of the AER, is that provincial regulators may be able to require compliance from insolvency professionals appointed over insolvent debtors even where their orders require the expenditure of funds outside of the normal manner of administration or distribution. In the authors' view, such a decision would be contrary to the Supreme Court of Canada's decision in AbitibiBowater, which is binding on superior and appellate courts in Canada.

The parties to the appeal of the Redwater proceedings have consented to an order which permits leave to appeal in exchange for the AER's agreement to transfer the licences associated with the retained Redwater in the event of a sale.

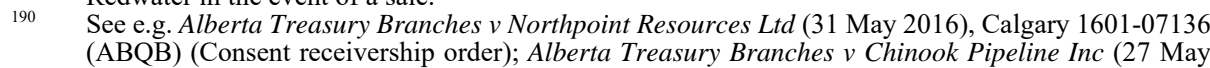
2016), Calgary 1601-06579 (ABQB) (Consent receivership order); Alberta Treasury Branches $v$ Nordegg Resources Inc (13 July 2016), Calgary 1601-07435 (ABQB) (Receivership amendment order); Alberta Treasury Branches v LGX Oil \& Gas Inc (7 June 2016), Calgary 1601-07315 (ABQB) (Consent receivership order).

191 Redwater, supra note 2 at paras 73-76. 
It is important to state that, should the AER and OWA be successful on appeal, the results could potentially dramatically affect how lenders and other parties who finance E\&P companies will treat the quantum of those liabilities. More specifically, if those abandonment and reclamation obligations are found to have a higher priority than senior secured lenders, it is likely that parties will treat them as present liabilities for the purpose of calculating the available credit for E\&P companies. This could have a significant effect on those E\&P companies' ability to finance exploration and development on a go forward basis.

\section{B. SUMMARY OF OPTIONS}

As previously mentioned, the practical challenges facing lenders in the current economic climate are numerous, and finding alternative options for recovery of outstanding loans requires considerable creativity. There are limited options available to lenders who are dealing with debtors with a deficient LMR.

Some options include:

- Appointing a receiver or trustee to facilitate the sale or disclaimer of the debtor's assets or negotiate with the AER to facilitate such sales;

- Cut off access to funding and collapse any hedge agreements which may be in the money to monetize that asset and then step back from any involvement with the assets. The uncertainty and costs associated with enforcement may lead to a further erosion of the value of the collateral or there may be no transaction that is capable of being consummated due to the position of the AER; and

- Support the debtor in some sort of consensual restructuring process. An amalgamation of two or more licensees or arrangement proceedings under a corporate statute may allow a debtor company to avoid issues surrounding transfer of the licences with the AER.

\section{REgUlator-Directed TRANSFERS}

An interested purchaser may also be able to purchase assets and secure the transfer of the corresponding licences through a non-routine regulator directed transfer (RDT). Although not expressly mentioned in the Redwater decision, the AER has the ability to approve the RDT of an AER licence to another licensee where one of the parties is "unable or unwilling to comply with the direction from the AER." 192

Pursuant to section 24(6) of the OGCA, the AER may direct the transfer of a licence to another licensee where one of the parties to a transfer is unable or unwilling to proceed with the transfer. A non-routine RDT occurs when the property is the subject of an RDT application and is also the subject of a breached abandonment order. ${ }^{193}$ In a non-routine RDT application, the AER will approve the transfer of the licences to a party provided that a 
$\$ 10,000$ per licence transfer fee (the RDT Fee) is paid before the transfer of properties is to proceed. ${ }^{194}$

In respect of Redwater, the AER required a security deposit to be posted far in excess of the RDT Fee per property before it would approve a transfer of any of Redwater's licences. The relevance of this RDT process to insolvency proceedings is that, incongruently, if the insolvency professional was discharged, a purchaser could simply apply to the AER by way of a RDT to have the necessary licence transfers approved, provided that the applicant pays the RDT Fee. While this option may run into some of the same constitutional issues discussed above if challenged, it offers both sellers and purchasers an opportunity to ensure the transfer of AER licences where litigation is too expensive to pursue or approval of a licence transfer transaction is in question.

\section{Negotiating With THE AER}

Creditors may also be able to negotiate an agreement with the AER that will allow a courtdirected sale to go forward. Generally, this may see some of the AER's unsecured claim be paid out in priority to secured creditors. Presently, this provides an option for lenders to secure the transfer of licences, and see some potential recovery on their loan, as long as an agreement can be reached. However, it also requires the agreement of the AER which is not certain and is likely dependent on the factual circumstances, in any given case.

An example of a lending syndicate negotiating an agreement with the AER can be found in the receivership proceedings of Spyglass Resources Corp. (Spyglass). Spyglass was an E\&P company with approximately 2,500 producing oil wells in Alberta. It experienced financial difficulties and decreased liquidity as a result of the extended depressed market prices for oil and gas resulting in a default under its credit agreement. As a result, its lenders subsequently applied to have a receiver appointed over the assets of Spyglass and its subsidiaries. ${ }^{195}$

The AER raised similar concerns about the transfer of licences in the proposed sales process of Spyglass as it did in Redwater's sales process. ${ }^{196}$ Its concerns focused on the LMR deficiency of Spyglass and how a sale could further negatively affect its LMR. Instead of litigating, the receiver entered into a sales agreement with the AER that facilitated the transfer of licences to a prospective purchaser (the Sale Agreement). ${ }^{197}$

The Sale Agreement was broken into two components. The first was where Spyglass's pro forma LMR was 1.0 or greater at the time the AER approved a transfer application and where it remained above 1.0 immediately following such a transfer. ${ }^{198}$ In such a case, all of the proceeds generated from the sale would be held for the benefit of Spyglass's estate. The proceeds would then be distributed by the receiver in accordance with applicable statutory priorities, the receivership order, and the receivership charges. ${ }^{199}$ 
The second component of the Sale Agreement dealt with a situation where Spyglass's pro forma LMR was either less than 1.0 at the time the AER approved a transfer application or was less than 1.0 immediately after the transfer. ${ }^{200}$ In that case, the receiver agreed to pay 50 percent of the maximum security deposit that Spyglass would have otherwise been required to post to the AER. ${ }^{201}$ Upon such payment, the AER agreed to deem Spyglass's LMR as 1.0 and approve the requested transfer of licences. This agreement allowed both the lenders and the AER to realize value without resorting to litigation that would either drain the estate or isolate the collateral. It is unclear how long the AER will remain amenable to such agreements now that the Redwater decision has been released. ${ }^{202}$

In the CCAA proceedings of Verity Energy Ltd (Verity), an application was brought by Verity in order to compel the AER to transfer certain AER licences to the purchaser in spite of the AER's demand for additional payment in order to rectify non-compliances by Verity. ${ }^{203}$ Even though the AER had initially supported the approval of the sale of the assets, it refused to transfer any of the licences to the purchaser unless an extra $\$ 150,000-\$ 200,000$ was provided to rectify Verity's LMR deficiency related to certain assets not being sold. ${ }^{204}$ The presiding commercial list justice ordered that, where the AER had supported the sales approval order, it was prevented from delaying or preventing a transfer to the purchaser based on its outstanding regulatory non-compliances that were not brought to the Court's attention at the time the sale was approved. ${ }^{205}$ It appears that the AER's discretion regarding licence transfers can be fettered by a court where it finds it appropriate to do so.

The AER released Bulletin 2016-16 on 20 June 2016, which outlines its interim regulatory response to Redwater. The bulletin announces three interim regulatory responses intended to alter the current licence transfer regime. ${ }^{206}$

Of particular concern to licensees and creditors was the new requirement that all transferees have an LMR of 2.0 or higher before the AER will approve a licence transfer. The new LMR requirements represent a significant departure from the current licence transfer requirements listed under Directive 006 , which previously only required a transferee to have an LMR of 1.0 or higher. For example, under the new LMR requirements, the AER would deny a licence transfer application even where the potential purchaser has an LMR of 1.65 and, as result of a sale, its LMR either remained the same or increased post-transfer but remained below 2.0 .

As of the 5 November 2016 LMR Report, only 237 of the 769 licensees in Alberta have an LMR of 2.0 or higher. ${ }^{207}$ Accordingly, the AER's interim policies have the effect of

\footnotetext{
Ibid.

Ibid.

Ibid.

Re Verity Energy Ltd (5 November 2015), Calgary 1501-04191 (ABQB) (Application (Alberta Energy Regulator Licenses)).

Ibid at 3 .

205 Re Verity Energy Ltd (16 November 2015), Calgary 1501-04191 (ABQB) (Order of the Honourable Justice Jeffery).

For more information, see Alberta Energy Regulator, "Licensee Eligibility - Alberta Energy Regulator Measures to Limit Environmental Impacts Pending Regulatory Changes to Address the Redwater Decision," Bulletin 2016-16 (Calgary: AER: 20 June 2016), online: <https://www.aer.ca/documents/ bulletins/Bulletin-2016-16.pdf>. 
reducing the number of eligible bidders for assets which, in turn, will reduce the sale price and further increase the owners' risk of becoming insolvent.

In response to criticism from industry and lenders, the AER softened its original stance and released Bulletin 2016-21, which clarifies its position regarding the new LMR requirements. Instead of strictly enforcing the new rule, the AER has stated it will look at proposed deals on a case-by-case basis and will consider whether a transferee is able to demonstrate that it will be able to meet its environmental obligations with an LMR of less than $2.0 .^{208}$

However, in order to increase the number of prospective bidders, ensure the integrity of sales processes, and maximize the value of a debtor's assets, court-appointed receivers and trustees may still be forced to disclaim all licenced assets that could lower a potential purchaser's LMR. As a result, and contrary to the AER's stated goals, the AER's new LMR policies will likely result in the opposite effect from what it intended and will undoubtedly increase the number of properties being sent to the OWA.

\section{E. BUSINESS CoRporation ACt OPTIONS}

Another alternative to guarantee the transfer of AER licences between parties includes amalgamations under provincial or federal business corporation statutes. Where an amalgamation takes place, the AER's policy is to automatically transfer licences into the name of the surviving entity because there are no specific change of control provisions triggered by such an arrangement. ${ }^{209}$

The same result can also be affected by a plan of arrangement. So long as the entity holding the licences does not change, underlying ownership changes will not generally attract or trigger the application of the AER's licence transfer requirements. However, in both cases, if the surviving entity has an LMR of below 1.0 after the amalgamation or arrangement, it will be required to post security in order to rectify the deficiency and may attract scrutiny from the AER given the recent changes in policy.

The complex and technical nature of these options are likely to result in increased costs. Amalgamations and plans of arrangement also have some execution risk associated with them. Unless the assets have significant value and the strong likelihood of an interested purchaser, secured creditors may not support a debtor through this process. Regulator's Measures to Limit Environmental Impacts Pending Regulatory Changes to Address the Redwater Decision," Bulletin 2016-21 (Calgary: AER, 8 July 2016), online: <https://www.aer.ca/ documents/bulletins/Bulletin-2016-21.pdf>. 


\section{Conclusion}

As noted above, the turbulence in the energy sector has resulted in certain unique and noteworthy insolvency proceedings which have the potential to shape the practice for the next several years. The final resolution of the Redwater proceedings will provide clarity and a path forward on the application of insolvency and environmental legislation and will likely have a direct impact on the policies and behaviour of provincial energy regulators with respect to insolvent licensees. Due to the limited number of reported insolvency decisions, the impact of Redwater cannot be understated and will have a direct impact on the lending and operating environment in Alberta, and Canada generally. 


\section{APpendix A}

\section{No trustee is bound to act}

14.06 (1) No trustee is bound to assume the duties of trustee in matters relating to assignments, bankruptcy orders or proposals, but having accepted an appointment in relation to those matters the trustee shall, until discharged or another trustee is appointed in the trustee's stead, perform the duties required of a trustee under this Act.

\section{Application}

(1.1) In subsections (1.2) to (6), a reference to a trustee means a trustee in a bankruptcy or proposal and includes

(a) an interim receiver;

(b) a receiver within the meaning of subsection 243(2); and

(c) any other person who has been lawfully appointed to take, or has lawfully taken, possession or control of any property of an insolvent person or a bankrupt that was acquired for, or is used in relation to, a business carried on by the insolvent person or bankrupt.

\section{No personal liability in respect of matters before appointment}

(1.2) Despite anything in federal or provincial law, if a trustee, in that position, carries on the business of a debtor or continues the employment of a debtor's employees, the trustee is not by reason of that fact personally liable in respect of a liability, including one as a successor employer,

(a) that is in respect of the employees or former employees of the debtor or a predecessor of the debtor or in respect of a pension plan for the benefit of those employees; and

(b) that exists before the trustee is appointed or that is calculated by reference to a period before the appointment.

\section{Status of liability}

(1.3) A liability referred to in subsection (1.2) is not to rank as costs of administration.

\section{Liability of other successor employers}

(1.4) Subsection (1.2) does not affect the liability of a successor employer other than the trustee. 


\section{Liability in respect of environmental matters}

(2) Notwithstanding anything in any federal or provincial law, a trustee is not personally liable in that position for any environmental condition that arose or environmental damage that occurred

(a) before the trustee's appointment; or

(b) after the trustee's appointment unless it is established that the condition arose or the damage occurred as a result of the trustee's gross negligence or wilful misconduct or, in the Province of Quebec, the trustee's gross or intentional fault.

\section{Reports, etc., still required}

(3) Nothing in subsection (2) exempts a trustee from any duty to report or make disclosure imposed by a law referred to in that subsection.

\section{Non-liability re certain orders}

(4) Notwithstanding anything in any federal or provincial law but subject to subsection (2), where an order is made which has the effect of requiring a trustee to remedy any environmental condition or environmental damage affecting property involved in a bankruptcy, proposal or receivership, the trustee is not personally liable for failure to comply with the order, and is not personally liable for any costs that are or would be incurred by any person in carrying out the terms of the order,

(a) if, within such time as is specified in the order, within ten days after the order is made if no time is so specified, within ten days after the appointment of the trustee, if the order is in effect when the trustee is appointed, or during the period of the stay referred to in paragraph (b), the trustee

(i) complies with the order, or

(ii) on notice to the person who issued the order, abandons, disposes of or otherwise releases any interest in any real property, or any right in any immovable, affected by the condition or damage;

(b) during the period of a stay of the order granted, on application made within the time specified in the order referred to in paragraph (a), within ten days after the order is made or within ten days after the appointment of the trustee, if the order is in effect when the trustee is appointed, by

(i) the court or body having jurisdiction under the law pursuant to which the order was made to enable the trustee to contest the order, or

(ii) the court having jurisdiction in bankruptcy for the purposes of assessing the economic viability of complying with the order; or 
(c) if the trustee had, before the order was made, abandoned or renounced or been divested of any interest in any real property, or any right in any immovable, affected by the condition or damage.

\section{Stay may be granted}

(5) The court may grant a stay of the order referred to in subsection (4) on such notice and for such period as the court deems necessary for the purpose of enabling the trustee to assess the economic viability of complying with the order.

\section{Costs for remedying not costs of administration}

(6) If the trustee has abandoned or renounced any interest in any real property, or any right in any immovable, affected by the environmental condition or environmental damage, claims for costs of remedying the condition or damage shall not rank as costs of administration.

\section{Priority of claims}

(7) Any claim by Her Majesty in right of Canada or a province against the debtor in a bankruptcy, proposal or receivership for costs of remedying any environmental condition or environmental damage affecting real property or an immovable of the debtor is secured by security on the real property or immovable affected by the environmental condition or environmental damage and on any other real property or immovable of the debtor that is contiguous with that real property or immovable and that is related to the activity that caused the environmental condition or environmental damage, and the security

(a) is enforceable in accordance with the law of the jurisdiction in which the real property or immovable is located, in the same way as a mortgage, hypothec or other security on real property or immovables; and

(b) ranks above any other claim, right, charge or security against the property, despite any other provision of this Act or anything in any other federal or provincial law.

\section{Claim for clean-up costs}

(8) Despite subsection 121(1), a claim against a debtor in a bankruptcy or proposal for the costs of remedying any environmental condition or environmental damage affecting real property or an immovable of the debtor shall be a provable claim, whether the condition arose or the damage occurred before or after the date of the filing of the proposal or the date of the bankruptcy. 